geology, natural history, and ethnology, with the view of rendering as exact as possible the information obtained regarding the region, its inhabitants, and products. As special subjects of investigation he is to observe and note the routes best adapted for future more extensive communication, and to spare no efforts in examining the range of mountains seen by Mr. E. D. Young and by Capt. Elton and his party, at the north-east end of Lake Nyassa, ascertaining their extent and elevation, and the condition of the routes or passes over them. The practicability of constructing a line of telegraph from north to south through the region is also to be inquired into. If Mr. Johnston should succeed in reaching Lake Tanganyika he is directed to pay special attention to facts bearing upon the extraordinary rise in its level in very recent times, as stated by Mr. Stanley. Besides making accurate measurements, Mr. Johnston is recommended to institute inquiries as to whether the rise may not be periodical, or the result of a succession of years of excessive rainfall ; but in the event of its proving continuous he is to investigate with care the causes and results of so remarkable a phenomenon. This note is followed by a summary of the survey arrangements of the Afghanistan Expedition, which promise to add much to our knowledge of the unknown tracts "of country on our north-west frontier. The information contained in the remaining notes has already been placed before our readers in our own columns. The maps in the present number are those of the Fly River, New Guinea, from Signor D'Albertis' survey, of the Sulimani Mountains, on our Afghan frontier, illustrating an article by Mr. C. R. Markham, and of the routes of the Swedish and Dutch Arctic Expeditions.

THE International African Association at Brussels have recently received intelligence that MM. Wautier and Dutrieux, with 360 porters, had left Mpwapwa on Cctober 15 to rejoin M. Cambier. On Octobex 27 they were at Mvumi, in Ugogo, where a letter from $M$. Cambier reached them, announcing his arrival at Kasisi, which is two days' march from Urambo, the capital of King Mirambo, of Unyamwesi. They are now travelling in company with M. Broyon, Mirambo's son-in-law, who is said to be taking up a large convoy to Ujiji for the English missionaries, and under his able guidance and advice it may be hoped that they will escape similar misfortunes to those which they have experienced in the past.

INTELLIGENCE has been received at St. Petersburg that Prof. Nordenskjöld's steamer $V e_{g} g a$ is ice-bound on the Siberian coast.

IN the last number of the Tour du Blonde, M. Alfred Marche, the former companion of M. Savorgnan de Brazza, in his explorations of Western Africa, concludes his admirably illustrated chapters, enititled "Voyage au Gabon et sur le Fleuve Ogooué."

PROF. KIEPERT, the eminent geographer, has recently expressed his opinion regarding the alleged return of the Amu Darya (or Oxus) into its ancient bed, and consequently becoming a tributary to the Caspian instead of the Aral Sea. The Professor remarks that all statements made hitherto, even as far back as those of the old Roman writers, are simple speculations, proving nothing else but merely the existence of a dry river-bed in the direction indicated. He thinks it a matter of course that, in the event of unusual accumulation of water in the Oxus, this bed may be filled with water for many miles' distance, and, during the few centuries for which we possess reliable data this event has happened so often, that the present recurrence need not in any way have given rise to so much talk and discussion.

Mr. E. F. IM THURN, of the British Guiana Museum, paid a visit, in October and November last, to the Kaieteur Fall of the Potaro River, for the purpose of testing whether it was rightly described by its discoverer,
Mr. Barrington Brown, as "one of the grandest falls in the world," as well as to prove the truth of his (Mr. im Thurn's) idea that such a place ought to be a rich treasure-ground for a collecting naturalist. He professes to be disappointed with the fall because it is neither so high as the Yosemité Fall nor so broad as Niagara. But he visited it when the water was at its lowest volume, and yet, when looking at it from above, he confesses that the fall is one of "splendid and awful beauty." Altogether we infer that Mr. Brown's description is essentially correct, especially when the river is at its fullest. The country on the road to and about the fall is described as of matchless beauty, and evidently it is a splendid field for a naturalist. The fall can be reached with comparative ease in a few days from Bartica Grove.

At the November meeting of the Russian Geographical Society, Admiral Krusenstern described the results of his journey to Siberia in 1876 to investigate the possibility of connecting the basin of the Petchora with that of the $\mathrm{Ob}$, and thus open a continuous water-way from Europe to Siberia. He reports favourably on the practicability of the scheme. The scientific results of the journey are topographical surveys, levellings of the principal parts of the route, a whole series of astronomical determinations, and a large addition to our knowledge of a region still little known.

THE last number of the Zeitschrift of the Berlin Geographical Society contains an elaborate paper by Herr G. Hartung on the formation of valleys and lakes. There is also a valuable paper by the late Saharan explorer, Erwin von Bary, on the character of the vegetation of Air; besides a large map of the African river Quanga, the result of the exploration of Herr Otto Schuit. The last two numbers of the Verhandlungen of the same Society contain some important papers. Prof. Karsten gives some data on the problem of ocean currents, and Dr. Tietze describes the resuits of his exploration of the volcanic Mount Demavend, to which we referred in a previous number. Dr. Hartmann has some interesting observations on the distribution of deep-sea animals. It will thus be seen that this Society regards geography as embracing a very wide field of research, and in this respect is a model that might with advantage be followed by other geographical societies.

A commitee has been formed at Berlin with the object of founding a "Central Union for Commercial Geography and the Furtherance of German Interests in Foreign Countries." The Society hopes to enter into friendly relations with all German and foreign geographical societies.

"Boswien in Bild und Wort," is the title of an interesting work by Amand von Schweiger Lerchenfeld, just published by Hartleben, of Vienna. The geographical publications of this frm are of particular excellence, and the present work is a fair case in point. It contains some twenty charming drawings from the artistic pen of $J$. J. Kirchner, illustrating the most interesting parts of the province which has played so prominent a part in the past year's history. 'The text is carefully written, clear, and to the point. Altogether the work is an acceptable addition to geographical literature.

\section{THE MARQUESS OF TWEEDDALE, P.Z.S.}

$\mathrm{T} \mathrm{T}$ is with extreme regret that we have to chronicle the death, after a three days' attack of bronchitis, on the morning of December 29, of Arthur Hay, ninth Marquess of Tweeddale, F.R.S., and President of the Zoological Society of London. Bom in 1824, the second son of Field-Marshal the late Lord Tweeddale, K.T., a veteran of the Peninsula and other campaigns of "the Great War," Lord Arthur Hay at an early age entered the army, as befitted the godchild of the grand English 
captain, and obtained a commission in the Grenadier Guards. But the ordinary guardsman's life in times of peace was inadequate to his aspirations, and reaching the rank of captain, he was soon after appointed aide-de-camp to Sir Henry (afterwards Lord) Hardinge, then GovernorGeneral of India, and in that capacity accompanied his chief through the ever-memorable campaign of the Sutlej. After the English arms had triumphed in the conquest of the Punjab, Lord Arthur was attached to a mission, the details of which, we believe, have never been made public, to some of the tribes bordering upon our northern frontier, and in discharge of that duty reached places unvisited by any European traveller since the days of Moorcroft. Lord Arthur's services in India and the adjacent countries lasted over several years, in the course of which time his attention was attracted by their rich and little-known fauna, and he not only formed the acquaintance, but assiduously cultivated the friendship of two of the greatest Indian zoologists of the time-Jerdon and Blyth-of whom he became an apt pupil, fishes and birds being particularly the objects of his pursuit. Returning home at length he resumed his regimental duties, and on the outbreak of the Russian war, in 1854, he accompanied the expeditionary force first to Turkey and thence to the Crimea, taking part in the operations which ended in the fall of Sebastopol. Soon after the conclusion of peace he left the army, and his old zoological tastes, which had been growing slack, returned to him more strongly than ever. On the death of his eldest brother, Lord Gifford, he became heir to his father's honours and estates, and assumed the courtesy title of Lord Walden, by which, perhaps, he will be most generally recognised, for under that designation he published the greater part of his contributions to zoology, and under it he succeeded the late Sir George Clerk as President of the Zoological Society, performing the duties of that office with a singular amount of dignity and urbanity. For several years he continued to live in a cottage he had built for himself at Chisleburst, and there he began to form an ornithological library and collection on a scale almost unattempted hitherto in this country, though the collection was supposed to be limited to Indian, or at least Asiatic, specimens. On the death of his father, at a very advanced age, in 1876 , Lord Walden inberited the Scottish peerage and estates, and thenceforth his home was mainly the old ancestral seat of Yester, near Haddington, where he entered, with the energy natural to his character, upon the life of an agriculturist ; in this respect following the example of his father, who had long since turned his sword into a ploughshare, and had earned the reputation of being one of the most scientific farmers in that part of North Britain, which is the headquarters of scientific farming.

The late Lord Tweeddale was a frequent and, when occasion required, a powerful writer. Most of his acknowledged communications are to be found in the Journal of the Asiatic Society of Bengal, the Ibis, and the Proceedings and Transactions of the Zoological Society, but it is believed that his anonymous contributions to the public press were still more numerous, though these were seldom on scientific topics. He married twice: first, the daughter of the late Count Kielmansegge, for many years the popular Minister of Hanover at this Court, who died in $187 \mathrm{r}$, and secondly, a daughter of Mr. Mackenzie of Seaforth, who survives him.

One word must be said of Lord Tweeddale's generosity. No reasonable project for the advancement of zoology in any of its branches was ever started but he was ready to support it liberally. His loss will be deeply felt by a wide circle of his brother ornithologists, and the Zoological Society will find it very difficult to replace him in its presidency, a post which seems to require a peculiar position of scientific and social rank.

\section{NOTES}

WE are happy to state that at the end of the last legislative session the French Central Bureau of Meteorology obtained from the National Exchequer a sum of 120,000 francs, required for the organisation of the services which were decreed in the month of June. A semi-monthly paper will be issued by the Bureau summarising the results of observations during that period. The work of norwal schools, which had been suspended during two or three years, will be resumed and published as in former times.

THE French Minister of Public Works has prepared a most important decree, which was signed on December 20 last. For the execution of the great works which have been voted by the French Parliament, an auxiliary corps of Ponts-et-Chaussées engineers has been created. The members of this newly created body will enjoy the same privileges as the government engineers who have been trained at the Polytechnic School. The consequence is that the privileges of that celebrated establishment are practically at an end, and the principle that office should be given to the fittest irrespective of their origin has a fair chance of becoming an axiom of the French administration.

THE first part of a posthumous work by Prof. Poggendorf on the History of Physics has been sent us by Messrs. Williams and Norgate. It will be completed in three parts and will contain much interesting matter collected by the late exinent physicist during his long career as lecturer at the Berlin University. We have also received the first part of the "Publications of the Astrophysical Observatory of Potsdam," containing observations of sun-spots from October, 1871, to December, 1873 , by Dr. Spörer.

From Science Nitus we learn that Mr. Alex. Agassiz left Cambridge (U.S.) on December I for a second dredying-trip in the West Indies on the Coast Survey steamer Blake. 'The specimens sccured by him are divided among scientific men in Europe and America, who work them up, while many of them go in'o his own Cambridge collection. This year he will cruise between the Windward Islands and the coast of South America, having spent last winter in the Gulf of Mexico.

THE prominence given to science is a noteworthy feature in the annual summaries for the past year which appear in most of our newspapers.

WE have much pleasure in drawing our readers' attention to the following circular concerning a Society for the Collection of South African Folk Lore. The circular explains itself, and we trust that those of our readers who are interested in the subject will subscribe to the periodical which it is desired to start:"The existence, among the aboriginal nations of South Africa, of a very extensive traditionary literature, is a well-known fact. Not a few stories forming part of this literature have been written down; and as in some of them terms occur which no longer appear to be used in colloquial language, and the meanings of which are, in many instances, not fully understood, there is no doubt that we meet in them with literary productions of great antiquity, handed down to the present generation in a somewhat similar manner to that in which the Homeric poems reached the age of Pisistratus. But European civilisation is gaining ground among the natives, and within a few years the opportunities for collecting South African folk-lore will be, if not altogether lost, at least far less frequent than they are now. This would be a great loss to 'the science of man,' particularly as there is much which is exceptionally primitive in the languages and ideas of the South African aboriginal races. There are not a few missionaries and other Europeans in South Africa who have ample opportunities for collecting South African folk-lore. Some of 